\title{
Motivasi Belajar Siswa Terhadap Penggunaan Macromedia Flash 8 Dimasa Pandemi Covid-19
}

Inda Mayana, Aulia Sthephani, Leo Adhar Effendi, Fitriana Yolanda

How to cite : Mayana, I., Sthephani, A., Effendi, L. A., \& Yolanda, F. (2021). Motivasi Belajar Siswa Terhadap Penggunaan Macromedia Flash 8 Dimasa Pandemi Covid-19. Kognitif: Jurnal Riset HOTS Pendidikan Matematika, 1(2), 144 -155. https://doi.org/10.51574/kognitif.v1i2.109

To link to this article : https://doi.org/10.51574/kognitif.v1i2.109

Opened Access Article

册 Published Online on 1 Desember 2021

特 Submit your paper to this journal 


\title{
Motivasi Belajar Siswa Terhadap Penggunaan Macromedia Flash 8 Dimasa Pandemi Covid-19
}

\author{
Inda Mayana $^{1 *}$, Aulia Sthephani ${ }^{1}$, Leo Adhar Effendi ${ }^{1}$, Fitriana Yolanda ${ }^{1}$ \\ ${ }^{1}$ Program Studi Pendidikan Matematika, Universitas Islam Riau (UIR)
}

\begin{tabular}{l} 
Article Info \\
\hline Article history: \\
Received Oct 6, 2021 \\
Accepted Oct 30, 2021 \\
Published Online Dec 1, 2021 \\
\hline
\end{tabular}

Keywords:

Matematika

Motivasi

Pembelajaran

Macromedia Flash 8

Pandemi Covid-19

\begin{abstract}
Di situasi saat ini yaitu Covid-19 meyebabkan seluruh pembelajaran dilakukan secara online. Dalam proses pembelajaran daring banyak kendala yang dialami terutama terhadap siswa, yang menyebabkan kurangnya minat untuk mengikuti pembelajaran matematika secara optimal. Sehubung dengan hal tersebut, guru harus memiliki berbagai cara untuk membangkitkan motivasi siswa ketika mengikuti pembelajaran yang berlangsung. Salah satunya adalah menggunakan media pembelajaran berbasis teknologi yaitu Macromedia Flash 8. Tujuan dari penelitian ini untuk mendeskripsikan motivasi belajar siswa terhadap penggunaan macromedia flash 8 di masa pandemi Covid-19. Jenis penelitiannya yaitu deskriptif dengan pendekatan kuantitatif, sampel penelitian ini adalah 20 siswa kelas X SMKN Pertanian Terpadu Provinsi Riau yang dipilih melalui teknik simple random sampling. Data didapat melalui google form yang berisikan pernyataan meliputi 4 aspek penilaian macromedia flash 8 yakni perhatian, relevansi, percaya diri, dan kepuasan. Pada hasil penelitian ini menunjukan adanya dampak positif terhadap motivasi belajar siswa dengan menggunakan macromedia flash 8 sebagai media pembelajaran dimasa pandemi dengan persentase rata-rata 71,5\%. Dari penelitian ini diperoleh bahwasanya macromedia flash 8 bisa menjadi media pembelajaran matematika di masa pandemi, karena memiliki berbagai keunggulan yang dapat meningkatkan motivasi belajar siswa.
\end{abstract}

This is an open access under the CC-BY-SA licence

All rights reserved.

\section{Corresponding Author:}

Aulia Sthephani,

Departemen Pendidikan Matematika,

Universitas Islam Riau ,

Jl. Kaharuddin Nasution No.113, Bukit Raya, Pekanbaru, Riau 28284, Indonesia.

Email: sthephania@edu.uir.ac.id

\section{Pendahuluan}

Pandemi Covid-19 bukan lagi hal yang asing bagi masyarakat di seluruh dunia. Dimana pandemi ini masih terjadi hingga saat ini, sehingga berdampak ke berbagai sektor aktivitas manusia diantaranya yaitu sektor pendidikan. Berdasarkan informasi mengenai pedoman Belajar Dari Rumah (BDR) menteri pendidikan dan kebudayaan nomor 4 tahun 2020, menyatakan semua kegiatan dalam proses pembelajaran dilakukan secara jarak jauh atau 
daring. Hal mengakibatkan kegiatan pembelajaran di sekolah berubah drastis, dimana pembelajaran secara langsung menjadi online, kemudian siswa dituntut untuk belajar secara mandiri pada kegiatan proses pembelajaran, serta semua kegiatan proses pembelajaran menggunakan teknologi (Asyura \& Dewi, 2020).

Perubahan keadaan yang mendadak diharapkan tidak mengganggu berjalannya proses pembelajaran matematika, terutama motivasi belajar siswa ketika mengikuti pembelajaran. Proses pembelajaran pada dasarnya memiliki peran penting untuk meningkatkan kualitas pembelajaran sehingga pembelajaran yang dilakukan berkualitas dan bermanfaat bagi peserta didik (Hammi, 2017). Dimana dengan keadaan Covid-19 hampir sebagian siswa yang merasakan kejenuhan ketika mengikuti proses pembelajaran daring yang mengakibatkan siswa kurang memperhatikan proses pembelajaran. Motivasi belajar adalah suatu proses yang meningkatkan, membimbing dan melestarikan kebiasaan siswa kepada tujuan pembelajaran tertentu sebab itu menggambarkan faktor-faktor yang dapat mendorong seseorang agar bersikap dengan cara tertentu (Bishara, 2018).

Bagi seluruh anak baik disetiap umur maupun tingkatan sangatlah penting untuk memiliki motivasi belajar. Motivasi digolongkan menjadi dua yaitu motivasi instrinsik dan ekstrinsik (Bishara, 2018). Motivasi instrinsik muncul dari dalam diri siswa itu sendiri yang biasanya tidak memerlukan dorongan dari faktor luar, sedangkan motivasi ekstrinstik muncul akibat adanya dorongan dari luar serta harus didukung dengan ruang lingkup belajar yang baik. Penelitian yang dilakukan dari perspektif behavioris membuktikan bahwasanya keberhasilan pada matematika ada pengaruh dari motivasi demi mencapai prestasi (Atit et al., 2020). Sehubung dengan hal tersebut, diperlukannya suatu trobosan yang menjadi solusi agar kegiatan proses belajar mengajar tetap berjalan secara optimal.

Salah satu bentuk trobosan yang bisa dibuat adalah dengan menggunakan media pembelajaran yang sesuai dan bisa meningkatkan motivasi belajar siswa. Pembelajaran akan tercapai dengan baik apabila mengunakan pendekatan atau strategi yang sesuai (Tarmizi \& Sthephani, 2020). Penggunaan media pembelajaran dalam proses pembelajaran matematika akan membuat lebih mudah, menarik serta menyenangkan. Pembelajaran dengan memanfaatkan media tidak hanya sekedar menggunakan verbal saja, tetapi juga menggunakan audio dan visual sehingga hasil pengalaman belajar menjadi lebih berarti bagi siswa (Munir, 2012). Dengan demikian media pembelajaran akan sangat berpengaruh pada proses pembelajaran karena akan meningkatkan motivasi belajar serta siswa akan lebih mudah memahami proses pembelajaran dan akan terangsang untuk belajar melalui media dengan maksud untuk mencapai tujuan pembelajaran.

Dalam hal pengembangan media pembelajaran, guru dituntut untuk bisa membuat pembelajaran yang kreatif, tidak membosankan dan bisa menarik minat siswa dalam belajar serta membuat proses pembelajaran lebih mudah untuk dimengerti (Susanti \& Suripah, 2021). Di masa Covid-19 ini, media pembelajaran bisa dikembangkan dengan memanfaatkan teknologi yang bisa mencegah keterbatasan ruang (Hasan, 2020). Berbagai jenis media yang bisa dipakai dalam proses pembelajaran online, seperti video pembelajaran ataupun modul yang bisa disebarkan lewat jaringan internet (Wulandari et al., 2020).

Meskipun ada berbagai fasilitas media pembelajaran yang bisa digunakan selama pembelajaran daring, namun siswa masih mengalami kesulitan dalam pemahaman maupun penguasaan konsep bilangan berpangkat tersebut, salah satu faktor penyebabnya adalah dimana guru kurang menarik dalam penyampaian materi sehingga siswa sulit untuk memahami konsep materi dan bosan dalam proses pembelajaran. Selain itu kebanyakan siswa masih sulit untuk memahami materi matematika yang telah dijelaskan, meskipun konsep materi tersebut berkaitan dengan kehidupan sehari-hari (Suripah \& Retnawati, 2019). Oleh sebab itu diperlukannya media yang dapat membangkitkan motivasi siswa ketika mengikuti 
pembelajaran serta tepat dipakai dalam proses pembelajaran online yang menjadi alternatif dan juga interaktif. Adapun media pembelajaran yang dapat dipergunakan ketika kegiatan pembelajaran online salah satunya yaitu macromedia flash 8 .

Macromedia flash 8 adalah suatu aplikasi yang dapat dimanfaatkan untuk mendesain dan membuat perangkat persentasi, publikasi, ataupun aplikasi lainnya yang memerlukan ketersediaan sarana interaksi bagi penggunanya. Hal ini didukung oleh Asyhar (2012: 187) yang menyatakan bahwa macromedia flash 8 adalah sebuah program aplikasi yang dimafaatkan untuk merancang suatu produk yang banyak digunakan pada sekarang ini. Proyek yang dibuat flash bisa terdiri dari gambar, teks, video, animasi sederhana, serta efek-efek lainnya. Aplikasi ini juga sudah dilengkapi dengan fitur actionscript untuk pembuatan animasi yang dapat membantu tampilan media pembelajaran menjadi lebih menarik dan coding (bahasa pemograman) tidak terlalu sulit untuk dipelajari bagi pemula yang menggunakan aplikasi macromedia flash 8 untuk membuat media pembelajaran. Berdsarkan hal tersebut menjadikan macromedia flash 8 sebagai media yang lebih bermakna terhadap siswa, menyenangkan, tidak membosankan, menarik, serta siswa bisa menjadi lebih aktif dalam proses pembelajaran karena bisa membuat pengalaman belajar menjadi lebih bermakna. Berbagai hasil penelitian menunjukan bahawa media pembelajaran dengan memanfaatkan macromedia flash 8 dapat meningkatkan motivasi siswa ketika mengikuti pembelajaran. Penelitian Ramadani (2018) aplikasi macromedia flash 8 ini mampu memberikan kemanfaatan dan kemudahan dalam proses pembelajaran bagi guru maupun siswa sehingga berpengaruh positif terhadap proses pembelajaran dan hasil belajar siswa. Sedangkan hasil penelitian yang dilakukan oleh Abu \& Hamsyah (2016) menunjukan bahwa dengan menggunakan macromedia flash 8 motivasi siswa dalam mengikuti pembelajaran lebih meningkat karena menarik perhatian siswa, dengan penyajian materi secara komunikatif dan siswa lebih banyak melakukan kegiatan pembelajaran. Yolanda \& Putri (2020) menjelaskan lebih lanjut kelebihan macromedia flash 8 dalam pembelajaran matematika yaitu: (1) menghasilkan bahan belajar matematika yang abstrak menjadi kongkrit, (2) membuat suasana belajar menjadi menarik dan mengurangi kejenuhan siswa selama proses pembelajaran berlangsung, (3) memberikan manfaat motivasi terhadap siswa dalam beraktivitas dan mendapatkan pengalaman belajar sehingga membuat hasil pembelajaran menjadi meningkat.

Berdasarkan hal tersebut, dengan memanfaatkan macromedia flash 8 sebagai media dalam proses pembelajaran menjadikan trobosan yang relevan dengan kemajuan teknologi, dikarenakan bisa menggabungkan multimedia interaktif berbentuk teks, gambar, animasi, audio dan video. Dalam kegiatan pembelajaran online akan sangat efektif memanfaatkan media yang bisa melengkapi bagian pokok proses pembelajaran yang bisa disatukan dengan ruang lingkup belajar siswa atau bisa melengkapi bagian digital learning ecosystem (Oktavian \& Aldya, 2020).

Penelitian yang dilakukan adalah penelitian yang berfokus terhadap penggunaan macromedia flash 8 yang dilihat dari aspek motivasi belajar siswa dimasa pandemi Covid-19. Tujuan dari penelitian ini untuk mendeskripsikan motivasi belajar siswa terhadap penggunaan macromedia flash 8 selama masa pandemi Covid-19.

\section{Metode}

Jenis penelitian ini merupakan penelitian deskriptif dengan pendekatan kuantitatif. Penelitian ini bertujuan untuk mendeskripsikan motivasi belajar siswa terhadap penggunaan 
macromedia flash 8 di masa pandemi Covid-19. Teknik pengambilan responden yaitu dengan cara teknik simple random sampling, dimana anggota sampel dari populasi tersebut (Sugiyono, 2015). Populasi pada penelitian ini yaitu siswa SMKN Prtanian Terpadu Provinsi Riau, sedangkan sampelnya adalah 20 siswa kelas X. Peneltian ini hanya dilakukan pada sebagaian siswa kelas $\mathrm{X}$, ini disebabkan karena adanya keterbatasan untuk melakukan penelitian di masa pandemi sekarang ini yang mengakibatkan peneliti melakukan penelitian secara online.

Instrumen dalam penelitian ini dibuat oleh peneliti, instrumen penelitian berupa kuesioner yang dibuat dari Google Form kemudian dibagikan kepada subjek penelitian dan untuk mengisi kuesioner, peneliti akan memberikan link pada subjek penelitian. Peneliti mengumpulkan data melalui kuesioner dari google form yang berisis pernyataan terkait aspek penilaian tentang macromedia flash 8 sebagai motivasi belajar siswa dari Janah et al., (2020) yang meliputi perhatian, relevansi, percaya diri, dan kepuasan yang bertujuan untuk mencari informasi yang lengkap. Kemudian peneliti memodifikasi indikator per aspek yang sesuai dengan kebutuhan peneliti. Jumlah seluruh angket motivasi belajar siswa yaitu 20 pernyataan, dimana 5 pertanyaan berisi tentang perhatian, 5 pertanyaan berisi tentang relevansi, 5 pertanyaan berisi tentang percaya diri, dan 5 pertanyaan berisi tentang kepuasan. Dimana setiap aspeknya memiliki 1 pernyataan ngatif dan 4 pernyataan positif.

Sebelum angket dibagikan kepada subjek penelitian, peneliti sebelumnya melakukan validitas terhadap isi standar kurikulum matematika SMK kelas X. validitas ini bertujuan untuk mengetahui kesesuaian antara materi dengan media pembelajaran yang akan diberikan kepada siswa. Pada tahap berikutnya, perangkat pembelajaran, media dan angket dikonsultasikan dengan para ahli, dimana ahli tersebut adalah 2 orang dosen pendidikan matematika. Berdasarkan saran yang sudah diberikan, peneliti merevisi sesuai dengan saran dan masukan tersebut hingga media yang telah peneliti buat dinyatakan valid. Sedangkan angket yang telah disusun berdasarkan indikator motivasi belajar menurut kajian teoritis untuk dijadikan butir angket motivasi belajar siswa. Butir-butir yang telah dibangun selanjutnya akan divaliditas oleh para ahli dan direvisi lebih lanjut sesuai saran ahli sampai angket dinyatakan valid.

Teknik analisis data memakai statistik deskriptif dengan bantuan komputerisasi dan pengolahan data dilakukan dengan cara menghitung persentase dari masing-masing aspek motivasi belajar siswa menggunakan macromedia flash 8 yang mencakup perhatian, relevansi, percaya diri, serta kepuasan. Setelah hasil yang didapatkan dari analisis data selanjutnya peneliti melakukan pengelompokkan, pengurutan, pengkategorian, dan perhitungan. Untuk pengkategorian motivasi belajar siswa bisa dilihat pada tabel di bawah ini:

Tabel 1. Kriteria Skor Motivasi Belajar Siswa

\begin{tabular}{ccl}
\hline No & \multicolumn{1}{c}{ Rentang Motivasi } & Kriteria Skor Motivasi Belajar Matematika \\
\hline 1. & $0 \% \leq$ Motivasi $\leq 20 \%$ & Motivasi yang sangat rendah \\
\hline 2. & $21 \% \leq$ Motivasi $\leq 40 \%$ & Motivasi rendah \\
\hline 3. & $41 \% \leq$ Motivasi $\leq 60 \%$ & motivasi yang cukup \\
\hline 4. & $61 \% \leq$ Motivasi $\leq 80 \%$ & Motivasi tinggi \\
\hline 5. & $81 \% \leq$ Motivasi $\leq 100 \%$ & Motivasi yang sangat tinggi
\end{tabular}

Sumber: Modifikasi Riduwan (2010) 


\section{Hasil Penelitian}

Salah satu contoh Macromedia Flash 8 yang peneliti gunakan dalam proses pembelajaran yaitu sebagai berikut:

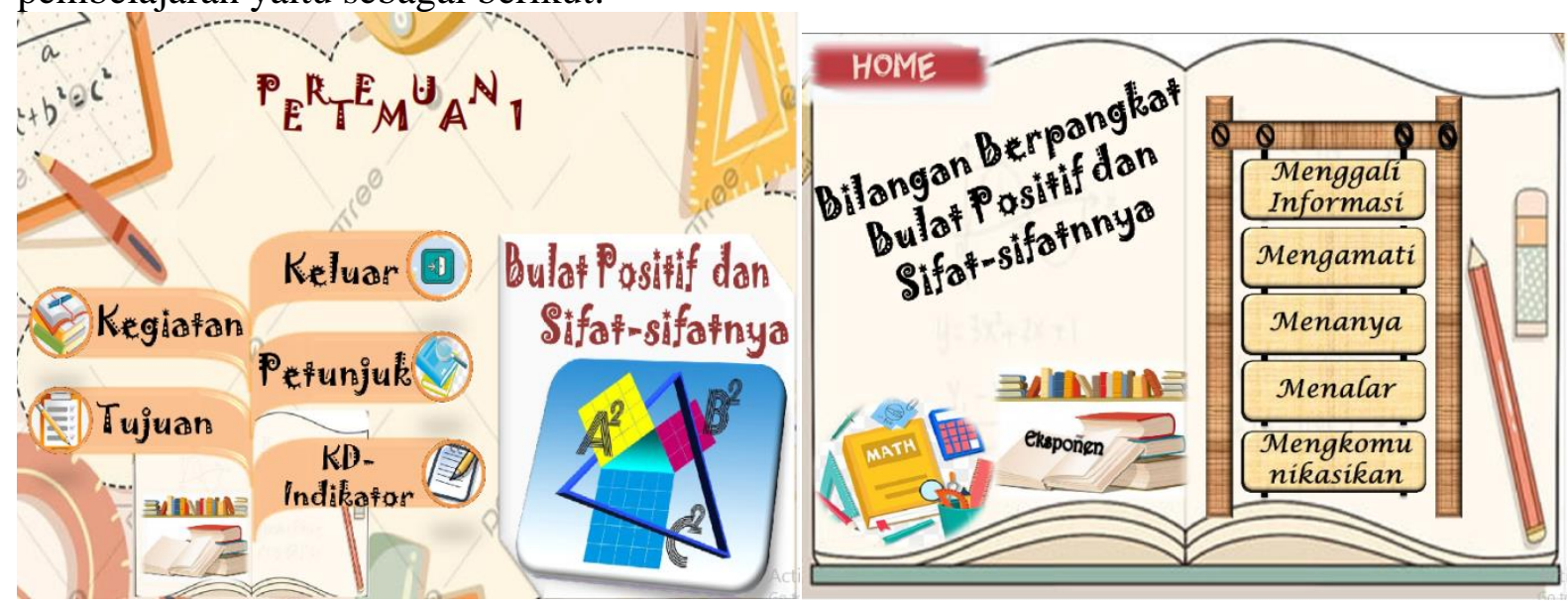

Gambar 1. Tampilan Salah Satu Macromedia Flash 8 yang Peneliti Gunakan dalam proses pembelajaran

Setelah siswa membuka dan mempelajari media pembelajaran yang peneliti berikan kemudian siswa mengisi kuesioner motivasi belajar. 20 siswa kelas X SMK Pertanian Terpadu Prov. Riau memberikan tanggapan terkait penggunaan macromedia flash 8 . Berikut merupakan hasil penilaian siswa:

Tabel 2. Hasil Survei Responden dalam Aspek Perhatian

\begin{tabular}{|c|c|c|c|c|c|}
\hline \multirow{2}{*}{ Aspek } & \multirow{2}{*}{ Indikator } & \multirow{2}{*}{ Butir } & \multicolumn{2}{|c|}{ Frekuensi } & \multirow{2}{*}{$\begin{array}{c}\text { Persentase } \\
(\%)\end{array}$} \\
\hline & & & Skor & $\begin{array}{c}\text { Jumlah } \\
\text { maksimum }\end{array}$ & \\
\hline \multirow{4}{*}{ Perhatian } & Rasa Senang & $\begin{array}{l}\text { Saya bersemangat mengikuti } \\
\text { proses pembelajaran } \\
\text { matematika menggunakan } \\
\text { macromedia flash } 8\end{array}$ & 79 & 100 & $79 \%$ \\
\hline & & $\begin{array}{l}\text { Saya senang mengerjakan } \\
\text { soal-soal yang ada di dalam } \\
\text { macromedia flash } 8\end{array}$ & 71 & 100 & $71 \%$ \\
\hline & \multirow[t]{2}{*}{$\begin{array}{c}\text { Keterlibatan } \\
\text { Siswa }\end{array}$} & $\begin{array}{l}\text { Saya cenderung pasif dalam } \\
\text { mengikuti proses } \\
\text { pembelajaran matematika } \\
\text { menggunakan macromedia } \\
\text { flash } 8\end{array}$ & 63 & 100 & $63 \%$ \\
\hline & & $\begin{array}{l}\text { Saya bersungguh-sungguh } \\
\text { mengerjakan apa yang }\end{array}$ & 72 & 100 & $72 \%$ \\
\hline
\end{tabular}




\begin{tabular}{lllll} 
& $\begin{array}{l}\text { diperintahkan dalam } \\
\text { macromedia flash 8 }\end{array}$ & & \\
Perhatian $\quad$ Minat Siswa & $\begin{array}{l}\text { Tampilan yang disajikan } \\
\text { dalam macromedia flash 8 } \\
\text { membuat saya sangat } \\
\text { tertarik untuk mengikuti } \\
\text { proses pembelajaran }\end{array}$ & 75 & 100 & $75 \%$ \\
\hline Total & & 360 & 500 & $360 \%$ \\
\hline Jumlah Persentase Total & & & $72 \%$ \\
\hline
\end{tabular}

Tabel 2 menunjukkan bahwa perhatian penggunaan macromedia flash 8 oleh siswa tinggi, terlihat dari jumlah persentase yaitu $72 \%$. Dari tabel tersebut terlihat bahwa $79 \%$ siswa bersemangat mengikuti proses pembelajaran matematika, $71 \%$ siswa senang dalam mengerjakan soal-soal yang ada di dalam macromedia flash, $72 \%$ siswa bersungguh-sungguh mengerjakan apa yang diperintahkan, dan $75 \%$ siswa tertarik dengan tampilan yang disajikan. Namun ada beberapa siswa yang masih cenderung pasif ketika mengikuti proses pembelajaran, hal ini terlihat dimana hanya $63 \%$ siswa yang aktif dalam proses pembelajaran.

Hasil survei responden yang dijadikan partisipan dalam penelitian ini menemukan bahwa pada macromedia flash 8 dapat menarik perhatian siswa, terlihat banyak siswa yang bersemangat dan tertarik mengikuti proses pembelajaran, serta memfokuskan perhatian dalam mengikuti pembelajaran matematika. Hal ini juga sejalan dengan penelitian (Setyawan \& Wahyuni, 2019) yang mengatakan bahwa dengan menggunakan media pembelajaran membuat siswa lebih memiliki daya tarik untuk memahami materi terlebih lagi dengan menggunakan macromedia flash.

Tabel 3. Hasil Survei Responden dalam Aspek Relevansi

\begin{tabular}{|c|c|c|c|c|c|}
\hline \multirow[b]{2}{*}{ Aspek } & \multirow[b]{2}{*}{ Indikator } & \multirow[b]{2}{*}{ Butir } & \multicolumn{2}{|c|}{ Frekuensi } & \multirow{2}{*}{$\begin{array}{c}\text { Persentase } \\
(\%)\end{array}$} \\
\hline & & & Skor & $\begin{array}{c}\text { Jumlah } \\
\text { maksimum }\end{array}$ & \\
\hline \multirow{2}{*}{ Relevansi } & \multirow{2}{*}{$\begin{array}{l}\text { Relevansi tema } \\
\text { dengan tujuan } \\
\text { pembelajaran } \\
\text { dan materi }\end{array}$} & $\begin{array}{l}\text { Video dan ilustrasi } \\
\text { pembelajaran yang } \\
\text { disajikan dalam } \\
\text { macromedia flash } 8 \\
\text { sesuai dengan tujuan } \\
\text { pembelajaran }\end{array}$ & 75 & 100 & $75 \%$ \\
\hline & & $\begin{array}{l}\text { Materi yang disajikan } \\
\text { dalam macromedia flash } \\
8 \text { tidak relevan dengan } \\
\text { kebutuhan saya, karena } \\
\text { sebagian isisnya tidak } \\
\text { saya ketahui }\end{array}$ & 69 & 100 & $69 \%$ \\
\hline \multirow[t]{2}{*}{ Relevansi } & \multirow[t]{2}{*}{$\begin{array}{c}\text { Relevansi } \\
\text { manfaat } \\
\text { pembelajaran } \\
\text { dengan } \\
\text { kebutuhan siswa }\end{array}$} & $\begin{array}{l}\text { Setelah membuka } \\
\text { macromedia flash } 8 \text { saya } \\
\text { yakin bahwa saya } \\
\text { mengetahui apa yang } \\
\text { harus saya pelajari dari } \\
\text { pembelajaran ini }\end{array}$ & 71 & 100 & $71 \%$ \\
\hline & & $\begin{array}{l}\text { Jelas bagi saya } \\
\text { bagaimana hubungan }\end{array}$ & 70 & 100 & $70 \%$ \\
\hline
\end{tabular}




\begin{tabular}{|c|c|c|c|c|c|}
\hline & & $\begin{array}{l}\text { materi pembelajaran di } \\
\text { dalam macromedia flash } \\
8 \text { dengan apa yang telah } \\
\text { saya ketahui }\end{array}$ & & & \\
\hline & $\begin{array}{c}\text { Relevansi metode } \\
\text { dengan materi }\end{array}$ & $\begin{array}{l}\text { Saya dapat } \\
\text { menghubungkan isi } \\
\text { pembelajaran ini dengan } \\
\text { hal-hal yang telah saya } \\
\text { lihat, saya lakukan, atau } \\
\text { saya pikirkan dalam } \\
\text { kehidupan sehari-hari }\end{array}$ & 65 & 100 & $65 \%$ \\
\hline Total & & & 350 & 500 & $350 \%$ \\
\hline Jumla & ntase Total & & & & $70 \%$ \\
\hline
\end{tabular}

Tabel 3 menunjukkan bahwa penggunaan macromedia flash 8 oleh siswa relevan, terlihat dari jumlah persentase yaitu 70\%. Dari tabel tersebut terlihat bahwa 75\% macromedia flash 8 sesuai dengan tujuan pembelajaran, $71 \%$ relevan dengan apa yang harus dipelajari siswa, $70 \%$ relevan dengan apa yang diketahui siswa. Namun ada beberapa siswa yang merasa bahwa materi yang disajikan masih belum relevan dengan kebutuhan siswa, hal ini terlihat dimana hanya $69 \%$ yang menyatakan materi yang disajikan relevan degan kebutuhan siswa, dan $65 \%$ siswa yang dapat menghubungkan materi dengan kehidupan sehari-hari.

Hasil survei responden yang dijadikan partisipan dalam penelitian ini menemukan bahwa penggunaan macromedia flash 8 oleh siswa sudah termasuk relevan, terlihat sebagian besar siswa menyatakan penggunaan macromedia flash 8 sudah sesuai dengan tujuan dan materi pembelajaran, kebutuhan siswa, serta adanya keterkaitan dengan kehidupan sehari-hari. Hal ini sejalan dengan Mardhiah \& Ali (2018) yang menyatakan bahwa isi pembelajaran yang sifatnya fakta, konsep, prinsip, atau generalisasi harus didukung oleh isi materi pembelajaran yang tepat dan jelas.

Tabel 4. Hasil Survei Responden dalam Aspek Percaya Diri

\begin{tabular}{|c|c|c|c|c|c|}
\hline \multirow[b]{2}{*}{ Aspek } & \multirow[b]{2}{*}{ Indikator } & \multirow[b]{2}{*}{ Butir } & \multicolumn{2}{|c|}{ Frekuensi } & \multirow{2}{*}{$\begin{array}{c}\text { Persentase } \\
(\%)\end{array}$} \\
\hline & & & Skor & $\begin{array}{c}\text { Jumlah } \\
\text { maksimum }\end{array}$ & \\
\hline \multirow{4}{*}{$\begin{array}{c}\text { Percaya } \\
\text { Diri }\end{array}$} & & $\begin{array}{l}\text { Saya kesulitan memahami } \\
\text { materi yang disajikan } \\
\text { dalam macromedia flash } 8\end{array}$ & 69 & 100 & $69 \%$ \\
\hline & $\begin{array}{l}\text { Dalam } \\
\text { memahami }\end{array}$ & $\begin{array}{l}\text { Saya lebih berkonsentrasi } \\
\text { dalam memahami materi } \\
\text { yang disajikan pada } \\
\text { macromedia flash } 8\end{array}$ & 74 & 100 & $74 \%$ \\
\hline & mater & $\begin{array}{l}\text { Saya lebih menikmati } \\
\text { proses pembelajaran } \\
\text { matematika dengan } \\
\text { menggunakan macromedia } \\
\text { flash } 8\end{array}$ & 73 & 100 & $73 \%$ \\
\hline & $\begin{array}{l}\text { Dalam } \\
\text { mengerjakan } \\
\text { soal }\end{array}$ & $\begin{array}{l}\text { Saya sangat antusias } \\
\text { mengerjakan soal-soal } \\
\text { yang ada pada macromedia } \\
\text { flash } 8\end{array}$ & 73 & 100 & $73 \%$ \\
\hline
\end{tabular}




\begin{tabular}{|c|c|c|c|c|}
\hline & $\begin{array}{l}\text { Saya tidak merasakan } \\
\text { kesulitan ketika } \\
\text { mengerjakan soal-soal } \\
\text { yang ada pada macromedia } \\
\text { flash } 8\end{array}$ & 70 & 100 & $70 \%$ \\
\hline Total & & 359 & 500 & $359 \%$ \\
\hline Jumlah Persentase Total & & & & $71,8 \%$ \\
\hline
\end{tabular}

Tabel 4 menunjukkan bahwa penggunaan macromedia flash 8 oleh siswa meningkatkan rasa percaya diri siswa, terlihat dari jumlah persentase yaitu $71,8 \%$. Dari tabel tersebut terlihat bahwa $74 \%$ siswa lebih berkonsentrasi dalam memahami materi, $73 \%$ siswa lebih menikmati proses pembelajaran, $73 \%$ siswa bersemangat mengerjakan soal-soal yang ada pada macromedia, dan $70 \%$ siswa tidak merasakan kesulitan ketika mengerjakan soal-soal yang ada pada macromedia. Namun ada beberapa siswa yang merasa kesulitan memahami materi yang disajikan dalam macromedia flash 8 , hal ini terlihat dimana hanya $69 \%$ siswa yang tidak kesulitan memahami materi yang disajikan dalam macromedia flash 8 .

Hasil survei responden yang dijadikan partisipan dalam penelitian ini menunjukan bahwa kepercayaan diri siswa dengan menggunakan macromedia flash 8 dalam pembelajaran tinggi, terlihat sebagian besar siswa berkonsentrasi dan antusias ketika memahami materi dan mengerjakan soal-soal yang ada, sehingga membuat hasil pembelajaran menjadi lebih optimal. Hal ini didukung oleh Wulansari, Telaga, \& Irawan (2019) yang menyatakan bahwa kepercayaan diri akan bisa berdampak positif terhadap motivasi belajar siswa yang membuat prestasi siswa menjadi lebih baik dan optimal.

Tabel 5. Hasil Survei Responden dalam Aspek Percaya Diri

\begin{tabular}{|c|c|c|c|c|c|}
\hline \multirow[b]{2}{*}{ Aspek } & \multirow[b]{2}{*}{ Indikator } & \multirow[b]{2}{*}{ Butir } & \multicolumn{2}{|c|}{ Frekuensi } & \multirow{2}{*}{$\begin{array}{c}\text { Persentase } \\
(\%)\end{array}$} \\
\hline & & & Skor & $\begin{array}{c}\text { Jumlah } \\
\text { maksimum }\end{array}$ & \\
\hline \multirow{5}{*}{ Kepuasan } & \multirow{3}{*}{$\begin{array}{l}\text { Dalam } \\
\text { memahami } \\
\text { materi }\end{array}$} & $\begin{array}{l}\text { Saya yakin menguasai } \\
\text { materi yang disajikan pada } \\
\text { macromedia flash } 8\end{array}$ & 70 & 100 & $69 \%$ \\
\hline & & $\begin{array}{l}\text { Sedikitpun saya tidak } \\
\text { memahami materi yang } \\
\text { disajikan dalam } \\
\text { macromedia flash } 8\end{array}$ & 70 & 100 & $70 \%$ \\
\hline & & $\begin{array}{l}\text { Setiap video dan ilustrasi } \\
\text { pembelajaran yang } \\
\text { disajikan dalam } \\
\text { macromedia flash } 8 \text {, saya } \\
\text { dapat memahaminya } \\
\text { dengan baik }\end{array}$ & 74 & 100 & $74 \%$ \\
\hline & \multirow{2}{*}{$\begin{array}{c}\text { Dalam hasil } \\
\text { belajar }\end{array}$} & $\begin{array}{l}\text { Saya yakin akan berhasil } \\
\text { dalam pembelajaran } \\
\text { matematika dengan } \\
\text { menggunakan macromedia } \\
\text { flash } 8\end{array}$ & 74 & 100 & $74 \%$ \\
\hline & & $\begin{array}{l}\text { Menyelesaikan tugas-tugas } \\
\text { dalam macromedia flash } 8 \\
\text { membuat saya merasa puas } \\
\text { terhadap hasil yang telah } \\
\text { saya capai }\end{array}$ & 73 & 100 & $73 \%$ \\
\hline
\end{tabular}




\begin{tabular}{llll}
\hline Total & 361 & 500 & $361 \%$ \\
\hline Jumlah Persentase Total & & & $72,2 \%$ \\
\hline
\end{tabular}

Tabel 5 menunjukkan bahwa penggunaan macromedia flash 8 oleh siswa memberikan kepuasan yang tinggi, terlihat dari jumlah persentase yaitu $72,2 \%$. Dari tabel tersebut terlihat bahwa $70 \%$ siswa memahami dan menguasai materi yang disajikan, $74 \%$ siswa memahami video dan ilustrasi pembelajaran serta akan berhasil dalam pembelajaran, dan $73 \%$ merasa puas akan hasil dalam menyelesaikan tugas-tugas yang ada dalam macromedia flash 8 . Hasil survei responden yang dijadikan partisipan dalam penelitian ini menunjukan bahwa sebagain besar siswa merasa puas dalam memahami materi dan hasil belajar yang didapatkan menggunakan macromedia flash 8. Berdasarkan aspek 1 sampai 4, total skor dapat divisualisasikan pada tabel berikut.

Tabel 6. Persentase Motivasi Belajar Siswa dengan Menggunakan Macromedia Flash 8

\begin{tabular}{clc} 
No & Aspek & Persentase (\%) \\
\hline 1. & Perhatian & $72 \%$ \\
\hline 2. & Relevansi & $70 \%$ \\
\hline 3. & Percaya Diri & $71,8 \%$ \\
\hline 4. & Kepuasan & $72,2 \%$ \\
\hline & & $\mathbf{7 1 , 5 \%}$
\end{tabular}

Tabel 6 menunjukkan persentase total setiap aspek penggunaan macromedia flash 8 sebagai media pembelajaran matematika terhadap motivasi belajar siswa. Berdasarkan skor motivasi belajar siswa yang bisa dilihat pada tabel 1, persentase rata-rata motivasi belajar siswa adalah $71,5 \%$. Sehingga berdasarkan hasil tersebut motivasi belajar siswa terhadap penggunaan macromedia flash 8 dimasa pandemi dapat dikategorikan tinggi.

\section{Diskusi}

Dengan keadaan dimasa pandemi ini dimana mengakibatkan pembelajaran dilakukan secara daring, guru dituntut untuk bisa membuat pembelajaran yang kreatif, dapat menarik perhatian siswa, tidak membosankan serta membuat pembelajaran lebih mudah untuk dimengerti. Hasil penelitian Cahyani et al (2020) diketahui bahwa penyebab menurunnya motivasi belajar siswa di masa pembelajaran online dikarenakan situasi pembelajaran yang mewajibkan siswa belajar sendiri di rumah sehingga guru tidak bisa membimbing siswa secara langsung sehingga guru tidak bisa memberikan reaksi memuji, memberi hadiah, dan memberi nasihat. Berdasarkan hal tersebut diperlukannya media pembelajaran yang bisa meningkatkan motivasi siswa dalam belajar yaitu berupa macromedia flash 8 .

Macromedia flash 8 merupakan media pembelajaran yang bisa dipakai pada proses pembelajaran di era saat ini dan interaktif untuk menumbuhkan motivasi belajar siswa. Interaktif media ini dapat dilihat dari respon siswa, sebagian besar siswa setuju jika macromedia 
flash 8 merupakan media pembelajaran yang interaktif dengan menggabungkan multimedia dalam penyampaian materi pembelajaran, berupa teks, audio, video, dan animasi. Hal ini sejalan dengan Fero (2011) menyatakan media pembelajaran macromedia flash 8 ini adalah media pembelajaran interaktif, dimana media pembelajaran ini dapat dipergunakan siswa kapan dan dimana saja. Selain itu Yolanda \& Putri (2020) menjelaskan macromedia flash 8 membuat suasana belajar menjadi menarik dan mengurangi kejenuhan siswa selama proses pembelajaran berlangsung, memberikan manfaat motivasi terhadap siswa untuk melakukan kegiatan, serta mendapatkan pengalaman dalam belajar yang membuat hasil pembelajaran siswa menjadi meningkat.

Dengan keunggulan tersebut, menjadikan macromedia flash 8 sebagai media pembelajaran yang lebih efektif digunakan selama kegiatan pembelajaran online. Hal ini terlihat dari hasil penelitian bahwa persentase rata-rata motivasi belajar siswa adalah $71,5 \%$. Sehingga berdasarkan hasil tersebut motivasi belajar siswa saat menggunakan macromedia flash 8 dimasa pandemi Covid-19 dapat dikategorikan tinggi. Hal ini menunjukan respon positif siswa pada penggunaan macromedia flash 8, dengan kata lain penggunaan macromedia flash 8 dalam proses pembelajaran matematika dapat meningkatkan motivasi belajar siswa.

\section{Simpulan}

Penggunaan macromedia flash 8 sebagai media pembelajaran matematika selama pembelajaran daring dapat meningkatkan motivasi belajar siswa. Dengan tampilan yang menarik, penyajian materi yang menarik menggunakan video, tidak membosankan, menyenangkan, dan informasi yang mudah dipahami membuat siswa lebih termotivasi dalam proses pembelajaran matematika. Perhatian dan rasa ingin tahu siswa ketika membuka materi pembelajaran matematika di macromedia flash 8 meningkatkan motivasi belajar mereka. Motivasi belajar siswa terhadap penggunaan macromedia flash 8 berada pada kategori tinggi, dengan persentase rata-rata 71,5\%. Berdasarkan hal tersebut menunjukan respon positif siswa terhadap penggunaan macromedia flash 8. Penggunaan macromedia flash 8 juga disarankan untuk digunakan dalam mata pelajaran lain.

\section{Konflik Kepentingan}

Penulis menyatakan tidak ada konflik kepentingan

\section{Referensi}

Abu, H. N., \& Hamsyah, E. F. (2016). Pengaruh Penggunaan Media Pembelajaran Berbasis Macromedia Flash 8 Terhadap Motivasi dan Hasil Belajar Kognitif Siswa Kelas VII SMPN 18 Makassar Studi pada Materi Pokok Asam, Basa dan Garam. Jurnal Chemica, 17(2), 12-18. https://doi.org/10.35580/chemica.v17i2.4680

Asyhar, R. (2012). Kreatif Mengembangkan Media Pembelajaran. Jakarta: Gaung Persada (GP) Press. 
Asyura, I., \& Dewi, R. (2020). Analisis Kemampuan Matematis Siswa PGSD terhadap Penggunaan Geogebra Classroom di Era dan Pasca Pandemi Covid-19. Jurnal Pendidikan Matematika, 4(2), 976-989. https://doi.org/10.31004/cendekia.v4i2.325

Atit, K., Power, J. R., Veurink, N., Uttal, D. H., Sorby, S., Panther, G., ... Carr, M. (2020). Examining the role of spatial skills and mathematics motivation on middle school mathematics achievement. International Journal of STEM Education, 7(1), 113. https://doi.org/10.1186/s40594-020-00234-3

Bishara, S. (2018). Active and Traditional Teaching, Self-image, and Motivation In Learning Math Among Pupils with Learning Disabilities. Cogent Education, 5(1), 116. https://doi.org/10.1080/2331186X.2018.1436123

Cahyani, A., Listiana, I. D., \& Larasati, S. S. D. (2020). Motivasi Belajar Siswa SMA pada Learning Daring di Masa Pandemi Covid-19. IQ (Ilmu Al-Qur'an): Jurnal Pendidikan Islam, 3(1), 123-140. https://doi.org/10.37542/iq.v3i01.57

Fero, D. (2011). Pengembangan Media Pembelajaran Menggunakan Macromedia Flash 8 Mata Pelajaran TIK Pokok Bahasan Fungsi dan Proses Kerja Peralatan TIK di SMA N 2 Banguntapan. Disertasi tidak dipublikasikan, Universitas Negeri Yogyakarta.

Hammi, Z. (2017). Implementasi Google Classroom pada Kelas XI IPA MAN 2 Kudus. Disertasi tidak dipublikasikan, Universitas Negeri Semarang.

Hasan, B. (2020). Pemanfaatan Google Classroom dalam Mata Kuliah Menggunakan Media Video Screencast O-Matic. Widya Wacana: Jurnal Ilmiah, 15(1), 915. https://doi.org/10.33061/j.w.wacana.v15i1.34884

Janah, A. N., S, W. A., Usman, M., \& Jumadi. (n.d.). Survei Motivasi Belajar Peserta Didik SMP Terhadap Pengadaan Pratikum pada Mata Pelajaran IPA. 1-6. Retrieved from https://doi.org/10.35542/osf.io/d4u8

Mardhiah, A., \& Akbar, S. A. (2018). Efektivitas Media Pembelajaran Terhadap Hasil Belajar Kimia Siswa SMA Negeri 16 Banda Aceh. Lantanida Journal, 6(1), 49-58.

Munir. (2012). Multimedia Konsep \& Aplikasi dalam Pendidikan. Bandung: Alfabeta.

Oktavian, R., \& Aldya, R. F. (2020). Efektivitas Pembelajaran Daring Terintegrasi di Era Pendidikan 4.0. Didaktis: Jurnal Pendidikan Dan Ilmu Pengetahuan, 20(1), 129135. https://doi.org/10.30651/didaktis.v20i2.4763

Ramadani, D. P. (2018). Pengembangan Media Pembelajaran Matematika Berbasis Macromedia Flash 8 Pada Materi Dimensi Tiga Kelas X SMA Smart Indonesia. Disertasi tidak dipublikasikan, Universitas Islam Riau.

Riduwan. (2010). Belajar Mudah Penelitian untuk Karyawan dan Peneliti Pemula. Bandung: Alfabeta. 
Setyawan, A. A., \& Wahyuni, P. (2019). Pengembangan Modul Ajar Berbasis Multimedia Pada Mata Kuliah Statistika Pendidikan. JPPM: Jurnal Penelitian Dan Pembelajaran Matematika, 12(1), 94-102.

Sugiyono. (2015). Metode Penelitian Kuantitatif, Kualitatif, dan R\&D. Bandung: Alfabeta.

Suripah, \& Retnawati, H. (2019). Student Mathematical Connection Ability in Representing Multiplication at the Elementary School. Journal of Physics: Conference Series, 1254(1). https://doi.org/10.1088/1742-6596/1254/1/012080

Susanti, W. D., \& Suripah, S. (2021). The Effectiveness of Website as a Mathematics Learning Media During the Online Learning Period. Edumatica : Jurnal Pendidikan Matematika, 11(01), 73-83. https://doi.org/10.22437/edumatica.v11i01.12225

Tarmizi, A., \& Sthephani, A. (2020). Perangkat Pembelajaran Matematika dengan Pendekatan Matematika Realistik (PMR) Berbasis Cerita Rakyat Melayu Riau. Jurnal AKSIOMATIK, 8(2), 51-59.

Wulandari, E., \& Nugroho, W. (2020). Sikap Siswa terhadap Video Pembelajaran Jarak Jauh Materi Statistika pada Media Sosial Youtube. Edumatica: Jurnal Pendidikan Matematika, 10(2), 1-9.

Wulansari, I. N., Tagela, U., \& Irwan, S. (2019). Hubungan Kepercayaan Diri dengan Motivasi Belajar Siswa Kelas X SMA Kristen Satya Wacana Salatiga. Genta Mulia: Jurnal Ilmiah Pendidikan, 10(1), 72-80.

Yolanda, F., \& Wahyuni, P. (2020). Pengembangan Bahan Ajar Berbantuan Macromedia Flash. SJME (Supremum Journal of Mathematics Education), 4(2), 170 177. https://doi.org/10.35706/sjme.v4i2.3612 